\title{
7qter DELETION WITH NORMAL HAGEMAN FACTOR
}

\author{
Hiroko KaWASHIMA and Noboru Taniguchi \\ Department of Pediatrics, School of Medicine, Kanazawa University, \\ Kanazawa 920, Japan
}

\begin{abstract}
Summary A 10-month-old boy with a 46,XY,del(7)(pter $\rightarrow$ q32:) karyotype is presented. Many of the clinical features of the patient are common with 11 previously reported cases except for the presence of congenital cardiac anomaly. There have been conflicting views as to the assignment of Hageman-factor locus to band $7 \mathrm{q} 35$. In the present case, the factor showed normal activity.
\end{abstract}

\section{INTRODUCTION}

In 1973 Shokeir et al. described the first case with terminal deletion (q32 $\rightarrow$ qter) of the long arm of chromosome 7 . Thereafter, 11 cases with similar chromosomal abnormalities were reported (de Grouchy et al., 1968; de Grouchy and Turleau, 1974; Harris et al., 1977a; Harris et al., 1977b; Kousseff et al., 1977; Biederman and Bowen, 1978; Friedrich et al., 1979; Bernstein et al., 1980).

In the present paper, a boy with $\operatorname{del}(7)($ pter $\rightarrow \mathrm{q} 32:)$ is presented. The karyotype and clinical features of this patient are compared with those of previously reported cases. Results of Hageman-factor assay were also described.

\section{CASE REPORT}

The patient, boy was the second child of healthy nonconsanguineous parents. The maternal age was 27 years and paternal age 33 at the time of the child's birth. There was no family history of congenital malformation and mental retardation. His birth weight was $1,390 \mathrm{~g}$ and product of 34 week uncomplicated gestation. He received an exchange transfusion at 7 th day of his life and was placed in an incubator for 3 months. He was fed by tube. He was reffered to the University Hospital at 10 months of age because of heart murmur and failure to thrive. On admission his height $(62.6 \mathrm{~cm})$, weight $(5,060 \mathrm{~g})$ and head circumference $(38.7 \mathrm{~cm})$ were all significantly below the 3 rd percentile. Physical examination revealed a small and hypotonic infant without head control. Physical abnormalities included microcephaly, frontal bossing, strabismus, prominent nose with bulbous tip, malformed ears, micrognathia, high arched palate, widely spaced nipples, heart murmur, sacral

Received December 1,1980 


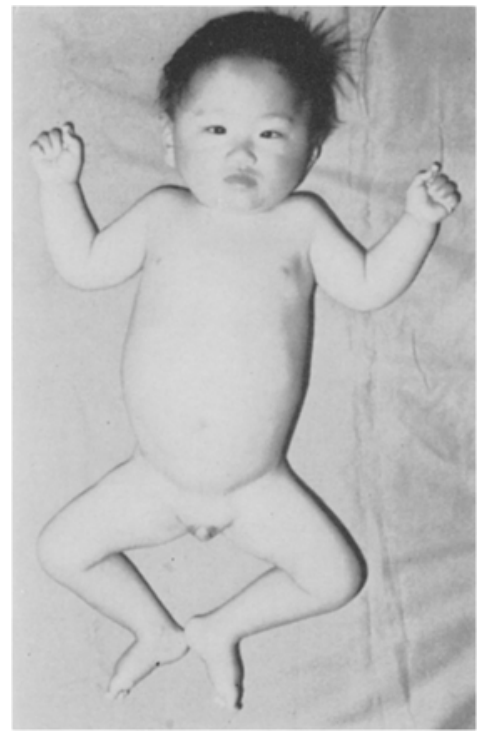

Fig. 1. Patient at 10 months of age.

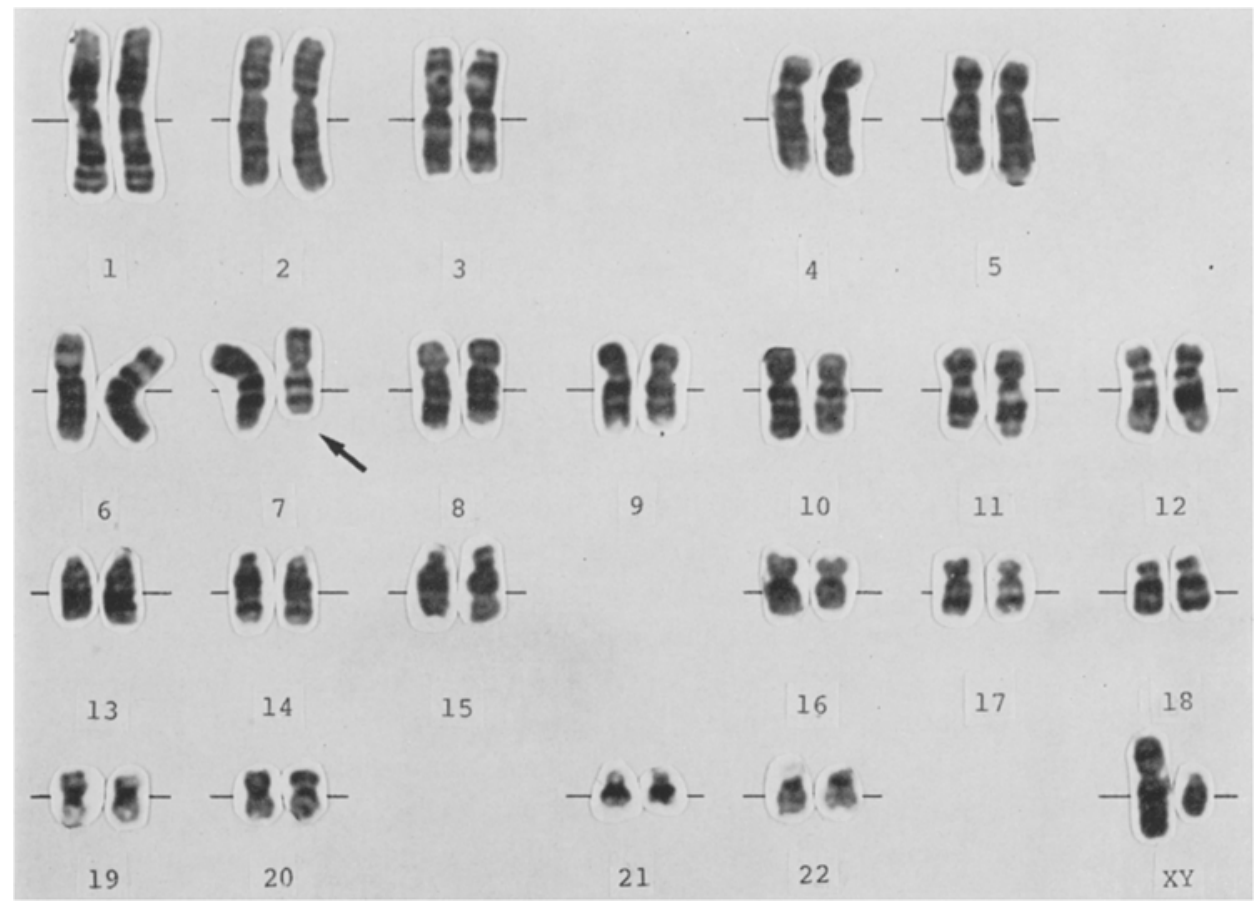

Fig. 2. Karyotype of the patient. Arrow indicates chromosome 7 with terminal deletion. 
dimple, bilateral cryptorchidism and hypospadia with small penis (Fig. 1).

Routine laboratory data were within normal ranges. Cardiac catheterization revealed patent ductus arteriosus with pulmonary hypertension. He was operated at 10 months of age. Since then, he became much active and there was some weight gain. He was still floppy without head control at the age of 13 months.

\section{CYTOGENETIC STUDY}

G-band analysis of chromosome on cultured lymphocytes revealed a probable terminal deletion of the long arm of a chromosome 7. The karyotype was interpreted as 46,XY,del(7)(pter $\rightarrow$ q32:) (Fig. 2). The parents had normal karyotypes with no evidence of translocation, insertion nor any other structural rearrangements.

\section{GENE MARKER STUDIES}

The activity of Hageman-factor was assayed by the method described by Biggs (1976), normal value being 50-200\%. The activity of Hageman-factor was $170 \%$ in the patient, $145 \%$ and $76 \%$ in his mother and father, respectively. They were all within the normal range.

\section{DISCUSSION}

A total of 15 cases of distal $7 \mathrm{q}$ monosomy have so far been described. It is noteworthy that in 12 of them, points of breakages were located at band $7 \mathrm{q} 32$. Ten cases, including the present case, had a seemingly identical karyotype, del(7)(pter $\rightarrow$ q32:) (Harris et al., 1977a; Harris et al., 1977b; Koussef et al., 1977; Biederman and Bowen, 1978; Friedrich et al., 1979; Bernstein et al., 1980). In two cases, deletion was associated with reciprocal translocation, i.e., $\mathrm{t}(6 ; 7)(\mathrm{p} 12 ; \mathrm{q} 32)$ and $\mathrm{t}(6 ; 7)$ (q25;q32), respectively (de Grouchy et al., 1968; Bernstein et al., 1980). In 11 of these cases, karyotype of the parents was examined and revealed a normal complement in 10 cases and $t(6 ; 7)(\mathrm{p} 25 ; \mathrm{q} 32)$ in the mother of Bernstein et al.'s case. In a case of Shokeir et al. (1973), parents were not examined.

Phenotypic features of these 12 cases were summarized in the Table 1. The present case appears to share most of the features with the other. Cardiac anomalies, however, was not observed in any other cases.

In the fifth issue of Human Gene Mapping (Evans et al., 1979) several genes were assigned to chromosome 7. Hageman-factor locus was included in them, however, it was ranked as inconsistent, i.e., conflicting results had been published. In 1974, de Grouchy and Turleau (1974) tentatively assigned it to 7q, presumably 7q35. On the other hand, in three cases of $\operatorname{del}(7)(\mathrm{q} 32)$, normal Hageman factor was observed (Biederman and Bowen, 1978; Bernstein et al., 1980). In two cases it was decreased (de Grouchy and Turleau, 1974; Friedrich et al., 1979), however, in one of them, both $7 q-$ propositus and the phenotypically normal father showed 
Table 1. Clinical features of distal $7 \mathrm{q}$ deletion.

\begin{tabular}{|c|c|c|c|c|c|c|}
\hline & \multirow{2}{*}{$\begin{array}{c}\text { Shokeir et al. } \\
\text { (1973) }\end{array}$} & \multirow{2}{*}{$\begin{array}{l}\text { de Grouchy } \\
\text { et al. } \\
(1974)\end{array}$} & \multicolumn{4}{|c|}{$\begin{array}{l}\text { Harris et al. } \\
(1977)\end{array}$} \\
\hline & & & case 1 & case 2 & case 3 & case 4 \\
\hline Sex & $\mathrm{Fa}^{\mathrm{a}}$ & $M^{b}$ & $\mathrm{~F}$ & $\mathrm{M}$ & $\mathrm{F}$ & $\mathrm{M}$ \\
\hline Mental retardation & + & + & + & + & + & + \\
\hline Growth retardation & + & + & + & + & + & + \\
\hline Microcephaly & ? & ? & ? & $?$ & + & - \\
\hline Prominent forehead & ? & + & + & + & - & $?$ \\
\hline Hypertelorism & + & $?$ & ? & $?$ & $?$ & - \\
\hline Eye anomalies & + & + & + & + & $?$ & $?$ \\
\hline Ear anomalies & $?$ & + & + & + & + & + \\
\hline Bulbous nasal tip & ? & + & + & + & + & ? \\
\hline Abnormal nasal bridge & - & + & $?$ & + & $?$ & + \\
\hline Large mouth & $?$ & ? & ? & + & + & $?$ \\
\hline Cleft lip, palate & - & ? & ? & $?$ & + & + \\
\hline Micrognathia & - & - & ? & ? & + & $?$ \\
\hline Cardiac anomalies & - & ? & $?$ & ? & $?$ & - \\
\hline Inguinal hernia & $?$ & + & $?$ & ? & + & + \\
\hline Genital anomalies & - & - & + & + & + & ? \\
\hline Distal limb anomalies & + & $?$ & + & + & + & $+\frac{1}{1}$ \\
\hline Hageman factor & $?$ & $\downarrow c$ & $?$ & $?$ & $?$ & $?$ \\
\hline \multirow[t]{3}{*}{ Karyotype } & $\begin{array}{l}t(2 ; 7) \rightarrow \\
\operatorname{del}(7)\end{array}$ & $\begin{array}{l}\mathrm{t}(6 ; 7) \\
(\mathrm{p} 12 ; \mathrm{q} 3\end{array}$ & $\begin{array}{l}\operatorname{del}(7) \\
(\mathrm{q} 32)\end{array}$ & $\begin{array}{l}\operatorname{del}(7) \\
(\mathrm{q} 32)\end{array}$ & $\begin{array}{l}\operatorname{del}(7) \\
\left(q^{3} 2\right)\end{array}$ & $\begin{array}{l}\operatorname{del}(7) \\
(\mathrm{q} 32)\end{array}$ \\
\hline & \multirow{2}{*}{$\begin{array}{l}\text { Kousseff } \\
\text { et al. } \\
(1977)\end{array}$} & \multirow{2}{*}{$\begin{array}{c}\text { Biederman } \\
\text { \& Bowen } \\
\text { (1978) }\end{array}$} & \multirow{2}{*}{$\begin{array}{l}\text { Friedrich } \\
\text { et al. } \\
(1979)\end{array}$} & \multicolumn{2}{|c|}{$\begin{array}{l}\text { Bernstein } \\
\text { et al. } \\
(1980)\end{array}$} & \multirow[t]{2}{*}{$\begin{array}{l}\text { Present } \\
\text { case } \\
(1980)\end{array}$} \\
\hline & & & & case 1 & case 2 & \\
\hline Sex & M & F & $\mathrm{F}$ & $\mathrm{M}$ & $\mathrm{F}$ & $\mathrm{MI}$ \\
\hline Mental retardation & $?$ & + & + & + & + & + \\
\hline Growth retardation & ? & + & + & + & + & + \\
\hline Microcephaly & + & + & + & + & + & + \\
\hline Prominent forehead & $?$ & $?$ & $?$ & + & + & + \\
\hline Hypertelorism & ? & - & $?$ & + & + & - \\
\hline Eye anomalies & ? & + & + & $?$ & $?$ & + \\
\hline Ear anomalies & ? & + & + & + & + & + \\
\hline Bulbous nasal tip & ? & $t$ & ? & $?$ & + & + \\
\hline Abnormal nasal bridge & ? & + & ? & + & + & - \\
\hline Large mouth & ? & $?$ & ? & ? & + & + \\
\hline Cleft lip, palate & ? & - & ? & + & ? & - \\
\hline Micrognathia & $?$ & $?$ & $?$ & + & $?$ & + \\
\hline Cardiac anomalies & ? & - & $?$ & $?$ & $?$ & + \\
\hline Inguinal hernia & ? & $?$ & ? & ? & ? & - \\
\hline Genital anomalies & + & + & ? & + & ? & + \\
\hline Distal limb anomalies & + & + & + & + & + & + \\
\hline Hageman factor & $?$ & $\rightarrow^{\mathrm{d}}$ & $\downarrow$ & $\rightarrow$ & $\rightarrow$ & $\rightarrow$ \\
\hline Karyotype & $\begin{array}{l}\operatorname{del}(7) \\
(q 32)\end{array}$ & $\begin{array}{l}\operatorname{del}(7) \\
(q 32)\end{array}$ & $\begin{array}{l}\operatorname{del}(7) \\
(\mathrm{q} 32)\end{array}$ & $\begin{array}{l}\mathrm{t}(6 ; 7) \\
(\mathrm{p} 25 ; \mathrm{q} 32)\end{array}$ & $\begin{array}{l}\operatorname{del}(7) \\
(\mathrm{q} 32)\end{array}$ & $\begin{array}{l}\operatorname{del}(7) \\
\text { (q32) }\end{array}$ \\
\hline
\end{tabular}

\& Female, b male, c decreased, d normal. 
a very low activity of Hageman factor (Friedrich et al., 1979). It was postulated that this particular case presented familial deficiency of the factor. In additional two cases, normal level was observed. In both of them the breakages were at band $7 \mathrm{q} 35$ (Francke, 1978; Turleau et al., 1979). It is possible that a part of this band, proximal to the break point, escaped deletion.

In the present case, the point of breakage was at band $7 \mathrm{q} 32$ and Hageman factor was within the normal limits in agreement with the concept that the factor was not located on 7q35 (Francke, 1978).

Acknowledgements The authors wish to express their thanks to Mr. H. Takai for performing the Hageman factor assay.

\section{REFERENCES}

Bernstein, R., Dawson, B., Morcom, G., Wagner, J., and Jenkinson, T. 1980. Two unrelated children with distal Iong arm deletion of chromosome 7: clinical features, cytogenetic and gene marker studies. Clin. Genet. 17: 228-238.

Biederman, B., and Bowen, P. 1978. Balanced $\mathbf{t}(8 ; 9)(\mathrm{q} 12 ; \mathrm{p} 33)$ pat carrier with phenotypic abnormalities atributable to a de novo terminal deletion of the long arm of chromosome 7. Hum. Genet. 41: 101-107.

Biggs, R. 1976. Human Blood Coagulation, Hemostasis and Thrombosis, 2nd Ed., Blackwell Scientific Corp.

De Grouchy, J., Veslot, J., Bonette, J., and Roidot, M. 1968. A case of ?6p-chromosomal aberration. Am. J. Dis. Child. 115: 93-99.

De Grouchy, J., and Turleau, C. 1974. Tentative localization of a Hageman (factor XII) locus on $7 \mathrm{q}$, probably the $7 \mathrm{q} 35$ band. Humangenetik 24: 197-200.

Evans, H.J., Hamerton, J.L., Klinger H.P., and MuKusik V.A. 1979. Human Gene Mapping 5. Cytogenet. Cell Genet. 25: no 1-4.

Fancke, U. 1978. Hageman (Factor XII) Locus on 7q? Hum. Genet. 45: 363-367.

Friedrich, U., Osterballe, O., Stenbjerg, S., and Jorgenson, J. 1979. A girl with karyotype 46,XX, del(7)(pter $\rightarrow$ q32:). Hum. Genet. 51: 231-235.

Harris, E.L., Wappner, R.S., and Palmer, C.G. 1977a. 7q deletion syndrome? New syndrome (The National Foundation-March of Dimes, Birth Defects; Original Article Series, Volume XIII number 3B), Alan R. Liss Inc., New York. p. 244.

Harris, E.L., Wappner, R.S., Palmer, C.G., Hall, B., Dinno, N., Seadhore, M.R., and Breg, W.R. 1977b. 7q deletion syndrome (7q32 $\rightarrow$ qter). Clin. Genet. 12: 233-238.

Kousseff, B.G., Hus, L.Y., Pacious, S., and Hirshhorn, K. 1977. A partial long arm deletion of chromosome 7: 46,XY,del(7)(q32). J. Med. Genet. 14: 144-147.

Shokeir, M.H.K., Ying, K.L.L., and Pabello, P. 1973. Deletion of the long arm of chromosome no. 7: tentative assignment of the Kidd(JK) locus. Clin. Genet. 4: 360-368.

Turleau, C., de Grouchy, J., Perignon, F., and Lenoir, G. 1979. Monosomie 7qter. Ann. de Genet. 22: 242-244. 